\title{
SISTEM KEAMANAN PENANGKAL PENCURIAN BAHAN PUSTAKA
}

\author{
Nur Heri Cahyana, ST., M.Kom \\ Jurusan Teknik Informatika FTI, UPN "Veteran" Yogyakarta \\ E_mail : dsnurheri@gmail.com
}

\begin{abstract}
Library materials (Library), which attracted many visitors seeking information library, the library collection according to its nature there are borrowed to take home and there was borrowed to be read in place, visitors to the library often has limited time to read diperpustakaan, so that not a few collections that often missing.

In this research, library materials security system is required to use RFID (Radio Frequency Identification). Which can mengidentifikasii affordable collection through frequency by putting RFID tags on the collection and RFID in the strategic area or the exit from the room so that the collection is out of the room will always be identified or read by the tool.

These systems provide data reports and books identified alarm sound from the instrument, if the collection is not allowed.
\end{abstract}

Keywords : Security System, RFID, Library

Bahan pustaka (koleksi Perpustakaan) yang banyak diminati para pengunjung perpustakaan yang mencari informasi, koleksi perpustakaan menurut sifatnya ada yang dipinjam untuk dibawa pulang dan ada yang dipinjam untuk dibaca ditempat, pengunjung perpustakaan sering memiliki keterbatasan waktu untuk membaca diperpustakaan, sehingga tidak sedikit koleksi yang sering hilang.

Pada penelitian ini diperlukan sistem keamanan bahan pustaka menggunakan RFID (Radio Frequency Identification). Yang dapat mengidentifikasii koleksi melalui frekuensi yang terjangkau dengan meletakan RFID tag pada koleksi dan RFID pada daerah strategis atau pintu keluar dari ruangan tersebut sehingga koleksi yang keluar ruangan akan selalu teridentifikasi atau terbaca oleh alat tersebut.

Sistem ini memberikan laporan data buku dan bunyi alarm yang teridentifikasi dari alat, jika koleksi tersebut tidak diijinkan.

Kata kunci : Sistem Keamanan, RFID, bahan pustaka

\section{PENDAHULUAN}

Untuk menjaga keamanan dan kenyamanan perpustakaan perlu antisipasi bila terjadi sesuatu seperti pencurian bahan pustaka, namun demikian sebagaimana kita tahu bahwa pepustakaan tidak hanya sebagai sumber belajar yang sangat penting, perpustakaan juga berfungsi sebagai pusat belajar mengajar, pusat informasi, pusat penelitian sederhana dan pusat rekreasi.

RFID atau Radio Frequency Identification, adalah suatu metode yang mana bisa digunakan untuk menyimpan atau menerima data secara jarak jauh dengan menggunakan suatu piranti yang bernama RFID tag atau transponder. Suatu RFID tag adalah sebuah benda kecil, misalnya berupa stiker adesif, dan dapat ditempelkan pada suatu barang atau produk. RFID tag berisi antena yang memungkinkan mereka untuk menerima dan merespon terhadap suatu query yang dipancarkan oleh suatu RFID transceiver.Sejarah RFID tag. Beberapa orang berpikir bahwa device pertama ditemukan oleh Leon Theremin sebagai suatu tool spionase untuk pemerintahan Rusia sekitar tahun 1945. Hal ini tidak benar sepenuhnya karena alamat Theremin ini sebenarnya suatu alat pendengar yang pasif dan bukan merupakan suatu identification tag. Teknologi yang digunakan oleh RFID sendiri sebenarnya sudah ada sejak tahun 1920 an. Suatu teknologi yang lebih dekat dengan RFID, yang dinamakan IFF transponder, beroperasi pada tahun 1939 dan digunakan oleh Inggris pada Perang Dunia II untuk

mengenali pesawat udara musuh atau teman 


\section{BAHAN DAN METODE}

RFID tag dapat bersifat aktif atau pasif. RFID tag yang pasif tidak memiliki power supply sendiri. Dengan hanya berbekal induksi listrik yang ada pada antena yang disebabkan oleh adanya frekuensi radio scanning yang masuk, sudah cukup untuk memberi kekuatan yang cukup bagi RFID tag untuk mengirimkan respon balik. Sehubungan dengan power dan biaya, maka respon dari suatu RFID yang pasif biasanya sederhana, hanya nomor ID saja. Dengan tidak adanya power supply pada RFID tag yang pasif maka akan menyebabkan semakin kecilnya ukuran dari RFID tag yang mungkin dibuat. Beberapa RFID komersial yang saat ini sudah beredar di pasaran ada yang bisa diletakkan di bawah kulit. Pada tahun 2005 tercatat bahwa RFID tag terkecil berukuran $0.4 \mathrm{~mm} \times 0.4 \mathrm{~mm}$ dan lebih tipis daripada selembar kertas. Dengan ukuran sekian maka secara praktis benda tersebut tidak akan terlihat oleh mata. RFID tag yang pasif ini memiliki jarak jangkauan yang berbeda mulai dari $10 \mathrm{~mm}$ sampai dengan 6 meter. RFID tag yang aktif, di sisi lain harus memiliki power supply sendiri dan memiliki jarak jangkauan yang lebih jauh. Memori yang dimilikinya juga lebih besar sehingga bisa menampung berbagai macam informasi di dalamnya. Sampai tulisan ini dipublikasikan, ukuran terkecil dari RFID tag yang aktif ini ada yang sebesar koin. Jarak jangkauan dari RFID tag yang aktif ini bisa sampai sekitar 10 meter dan dengan umur baterai yang bisa mencapai beberapa tahun lamanya.

Pada dasarnya RFID terdiri dari empat komponen, yaitu diantaranya (www.patrickplaggenburg.nl) :

\subsection{Tag}

Tag adalah alat yang digunakan untuk menyimpan informasi untuk identifikasi objek. Tag sering juga disebut sebagai transponder. Komponen utama dari tag yaitu chip dan antena tag, dimana chip berisi nomor seri yang unik atau informasi lainnya tergantung pada tipe memorinya, tipe memori itu sendiri dapat read-only, read-write, atau write-once readmany. Antena yang terpasang pada tag (antena tag) sebagai penghubung antara reader dengan tag. Informasi yang berada/tersimpan dalam chip ini akan terkirim/terbaca melalui gelombang elektromagnetik setelah antena tag mendapatkan/menerima pancaran gelombang elektromagnetik dari antena reader (Interogator).

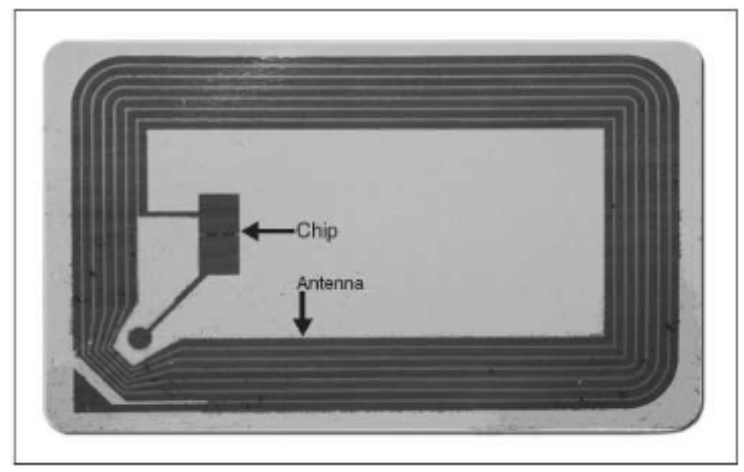

Gambar 2.1 Tag RFID.

Tag mempunyai beberapa tipe, diantaranya :

1) Tag Pasif

Yaitu tag yang tidak memiliki catu daya sendiri, sehingga memperoleh daya dari medan gelombang elektromagnet yang dihasilkan oleh reader RFID. Ketika antena tag dipengaruhi oleh sinyal frekuensi radio yang datang dari reader RFID, maka akan timbul daya yang cukup pada tag RFID untuk mengirimkan sebuah respon. Karena daya yang terbatas tersebut, maka respon dari RFID tag pasif hanyalah berupa sebuah laporan singkat, pada umumnya hanya berupa nomor ID saja. Tipe memori umumnya read-only. Jadi daya yang berasal dari reader RFID hanya dapat digunakan untuk menjalankan chip dan komunikasi. Jangkauan baca tag pasif $10 \mathrm{~cm}-10 \mathrm{~m}$ (tergantung dari antena). Usia tag dapat mencapai 20 tahun. Harga tag pasif lebih murah dibanding dengan tipe tag lainnya.

2) Tag Semipasif 
Tag yang memiliki catu daya sendiri tetapi hanya dapat digunakan untuk menjalankan chip, jadi memerlukan daya dari medan gelombang elektromagnet dari reader untuk berkomunikasi. Jangkauan baca tag semipasif dapat mencapai $31 \mathrm{~m}$. Tipe memorinya read-write. Usia tag 2 sampai 7 tahun. Harga tag semipasif lebih mahal daripada tag pasif.

3) Tag Aktif

Selain tag memiliki catu daya sendiri juga memiliki pemancar sendiri sehingga dapat mengirimkan sinyal secara kontinyu. Jadi jangkauan bacanya lebih jauh (sekitar 228,6 m) dan mempunyai kapasitas memori yang lebih besar (tipe memorinya read-write). Daya yang ada digunakan untuk menjalankan chip serta untuk berkomunikasi dengan reader tanpa harus berada dalam medan gelombang elektromagnet. Usia tag 5 sampai 10 tahun. Harga tag aktif paling mahal dibanding tag tipe lainnya.

\subsection{Reader}

Pembaca RFID merupakan penghubung antara software aplikasi dengan antena yang akan meradiasikan gelombang radio ke tag RFID. Didalam reader terdapat antena, transceiver dan decoder, yang berfungsi memancarkan sinyal yang bisa mengaktifkan tag RFID sehingga reader dapat membaca dan menulis data ke dalam tag (atau reader dapat menerima dan mengirim data dari tag). Ketika suatu tag RFID melewati suatu wilayah elektromagnetik, maka tag akan mendeteksi sinyal aktivasi yang dipancarkan oleh reader, tag akan mengirimkan sinyal balik sebagai balasan. Reader akan men-decode data yang ada pada tag dan kemudian data tersebut akan diproses oleh komputer.

\subsection{Antena}

Antena untuk mentransmisikan sinyal frekuensi radio antara reader dengan tag, antena merupakan unsur yang penting karena juga untuk menentukan jarak baca antara reader dengan tag dan juga seberapa luas area pembacaan, antena dapat dikategorikan dalam dua model koneksi, yaitu : Integrated antena yang dibutuhkan jika jarak pembacaan tidak begitu luas. Dan external antena yang dibutuhkan jika jarak pembacaan memerlukan area yang luas. Berikut ini adalah empat frekuensi utama yang digunakan oleh sistem RFID (www.cert.or.id):

1) Band LF berkisar dari 125 kilohertz $(\mathrm{KHz})$ hingga $134 \mathrm{KHz}$. Band ini paling sesuai untuk penggunaan jarak pendek (short-range) seperti sistem antipencurian, identifikasi hewan dan sistem kunci mobil.

2) Band HF beroperasi pada 13.56 megahertz (MHz). Frekuensi ini memungkinkan akurasi yang lebih baik dalam jarak tiga kaki dan karena itu dapat mereduksi resiko kesalahan pembacaan tag. Sebagai konsekuensinya band ini lebih cocok untuk pembacaan pada tingkat item (item-level reading). Tag pasif dengan frekuensi 13.56 $\mathrm{MHz}$ dapat dibaca dengan laju 10 sampai 100 tag perdetik pada jarak tiga kaki atau kurang. Tag HF digunakan untuk pelacakan barang-barang di perpustakaan, toko buku, kontrol akses gedung, pelacakan bagasi pesawat terbang, pelacakan item pakaian.

3) Tag dengan band UHF beroperasi di sekitar $900 \mathrm{MHz}$ dan dapat dibaca dari jarak yang lebih jauh dari tag HF, berkisar dari 3 hingga 15 kaki. Tag ini lebih sensitif terhadap faktor-faktor lingkungan daripada tag-tag yang beroperasi pada frekuensi lainnya. Band $900 \mathrm{MHz}$ muncul sebagai band yang lebih disukai untuk aplikasi rantai supply disebabkan laju dan rentang bacanya. Tag UHF pasif dapat dibaca dengan laju sekitar 100 hingga 1.000 tag perdetik. Tag ini umumnya digunakan pada pelacakan kontainer, truk, trailer, terminal peti kemas, serta telah diadopsi oleh peritel besar dan Departemen Pertahanan Amerika Serikat. Sebagai tambahan, di Amerika serikat, band $\mathrm{MHz}$ digunakan untuk mengidentifikasi isi kontainer dalam area komersial dan industri untuk meningkatkan ketepatan waktu dan akurasi transmisi data. Menurut FCC penggunaan semacam itu menguntungkan perusahaan pengapalan komersial dan memberikan manfaat keamanan yang signifikan dengan dimungkinkannya seluruh isi kontnainer teridentifikasi dengan mudah dan cepat serta dengan dapat diidentifikasinya kerusakan selama pengapalan.

4) Tag yang beroperasi pada frekuensi gelombang mikro, biasanya 2.45 dan 5.8 gigahertz $(\mathrm{GHz})$, mengalami lebih banyak pantulan gelombang radio dari obyek-obyek di dekatnya yang dapat mengganggu kemampuan reader untuk berkomunikasi dengan tag. Tag gelombang mikro biasanya digunakan untuk manajemen rantai supply. 


\subsection{Software aplikasi}

Aplikasi pada sebuah sistem komputer yang mengatur alur informasi dari item-item yang terdeteksi dalam lingkup sistem RFID dan mengatur komunikasi antara tag dan reader (membaca data dari tag melalui reader, baik tag dan reader dilengkapi dengan antena sehingga dapat menerima dan memancarkan gelombang elektromagnetik). Host bisa berupa komputer stand-alone maupun terhubung ke jaringan LAN / Internet untuk komunikasi dengan server.

\section{HASIL DAN PEMBAHASAN}

Sistem keamanan menggunakan teknologi RFID, yaitu sebuah metode identifikasi dengan menggunakan sarana yang disebut label RFID atau transporder/tag untuk menyimpan dan mengambil data jarak jauh. Label atau kartu RFID sebuah alat yang bisa dipasang atau dimasukkan dalam koleksi, dengan tujuan untuk identifikasi menggunakan gelombang radio yang akan dibaca oleh reader RFID. Dengan bantuan teknologi RFID diharapkan dapat dimanfaatkan untuk membantu petugas perpustakaan dalam menjaga dan mengamankan media informasi pustaka, Sistem berfungsi sebagai pendeteksi keberadaan media informasi pustaka yang disembunyikan, dan dapat memberikan informasi berupa laporan yang ditampilkan pada layar monitor komputer.

\subsection{Arsitektur Sistem}

Sistem yang akan dibangun menggunakan RFID Starter Kit dan tag pasif berbentuk kartu. Reader terhubung dengan komputer melalui serial port.

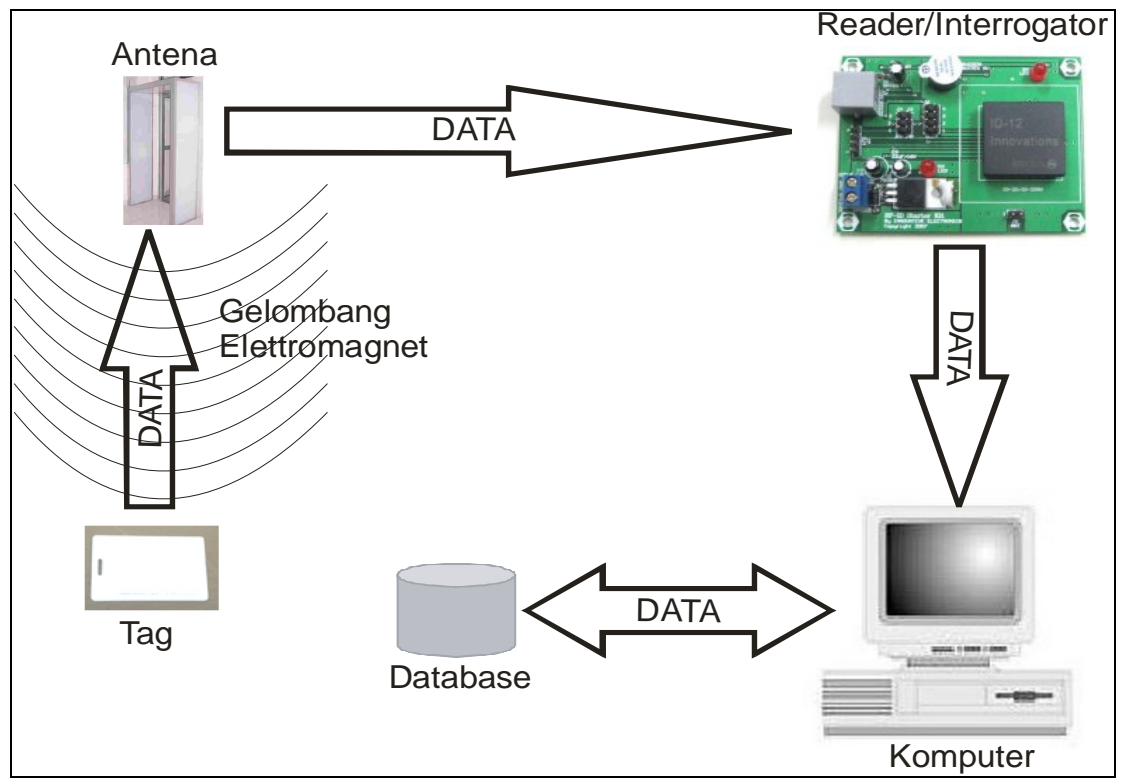

Gambar 3.1 Arsitektur Sistem

\subsection{Perancangan Proses}

Pendekatan perancangan yang akan digunakan adalah pendekatan bagan alir yang menjelaskan bagaimana alir dalam fungsi-fungsi sistem secara logikal. 


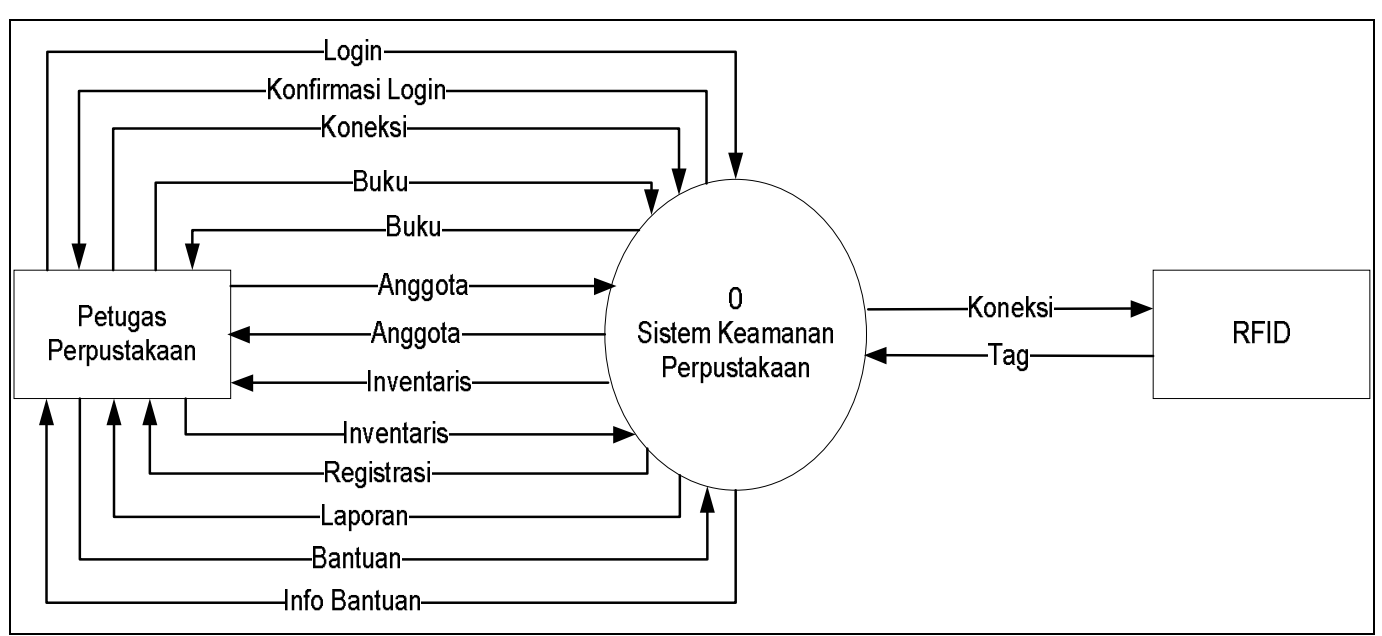

Gambar 3.2 DFD level 0

Pemakai sistem ini adalah petugas perpustakaan, yang harus login terlebih dahulu bila ingin mengolah data sistem dan mendapatkan laporan, setelah login petugas perpustakaan belum dapat mengubah data login dan belum dapat memilih pilihan yang disediakan oleh sistem, karena harus dilakukan koneksi port terlebih dahulu ( proses koneksi port akan dibahas dalam flowchart koneksi port ).

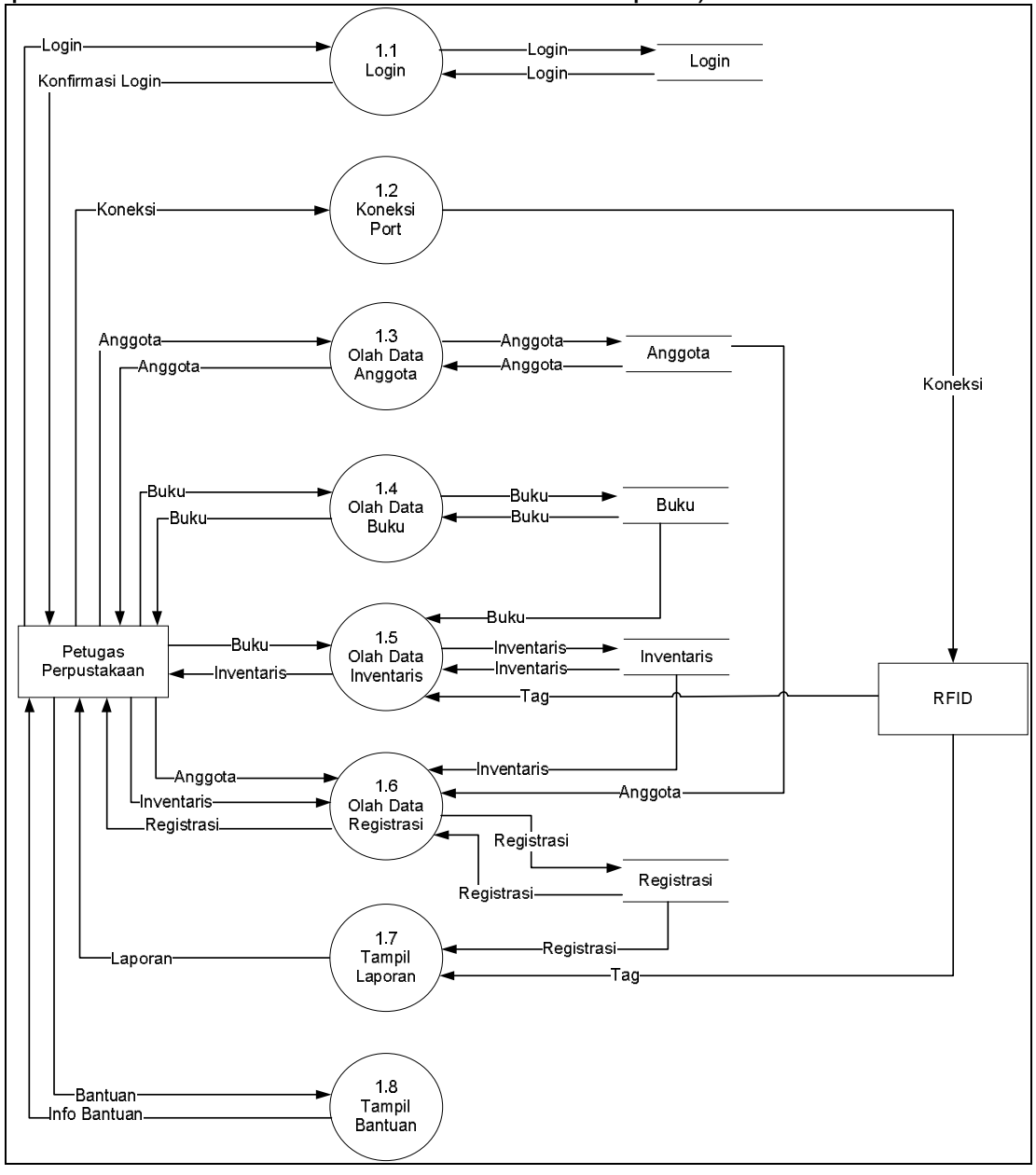

Gambar 3.3 DFD Level 1

Gambar 3.3 menggambarkan petugas perpustakaan terlebih dahulu mengaktifkan port yang terdapat dalam menu utama agar RFID terhubung ke komputer sehingga menu utama dapat 
aktif dan dapat mengolah data lainnya, seperti mengolah data anggota, mengolah data buku, mengolah data inventaris dan mengolah data registrasi. Petugas perpustakaan akan mendapat laporan apabila ada media informasi pustaka yang keluar tanpa registrasi.

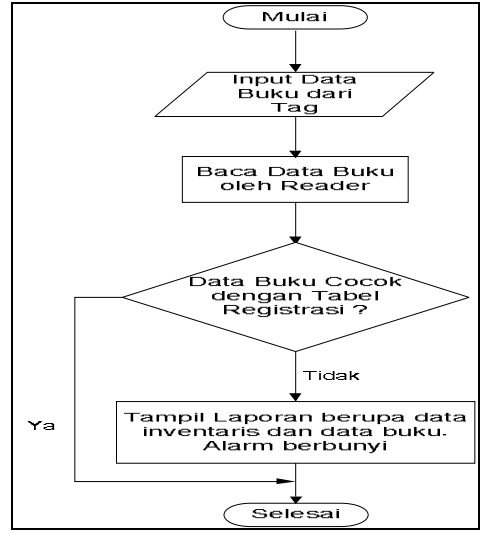

Gambar 3.4 Flowchart Laporan

Gambar 3.4 merupakan alir untuk menampilkan laporan bila ada media informasi pustaka yang keluar tanpa registrasi

\subsection{Basisdata}

Gambar 3.5 entitas yang direlasikan untuk menampilkan laporan dan berfungsi sebagai informasi buku diijinkan atau tidak

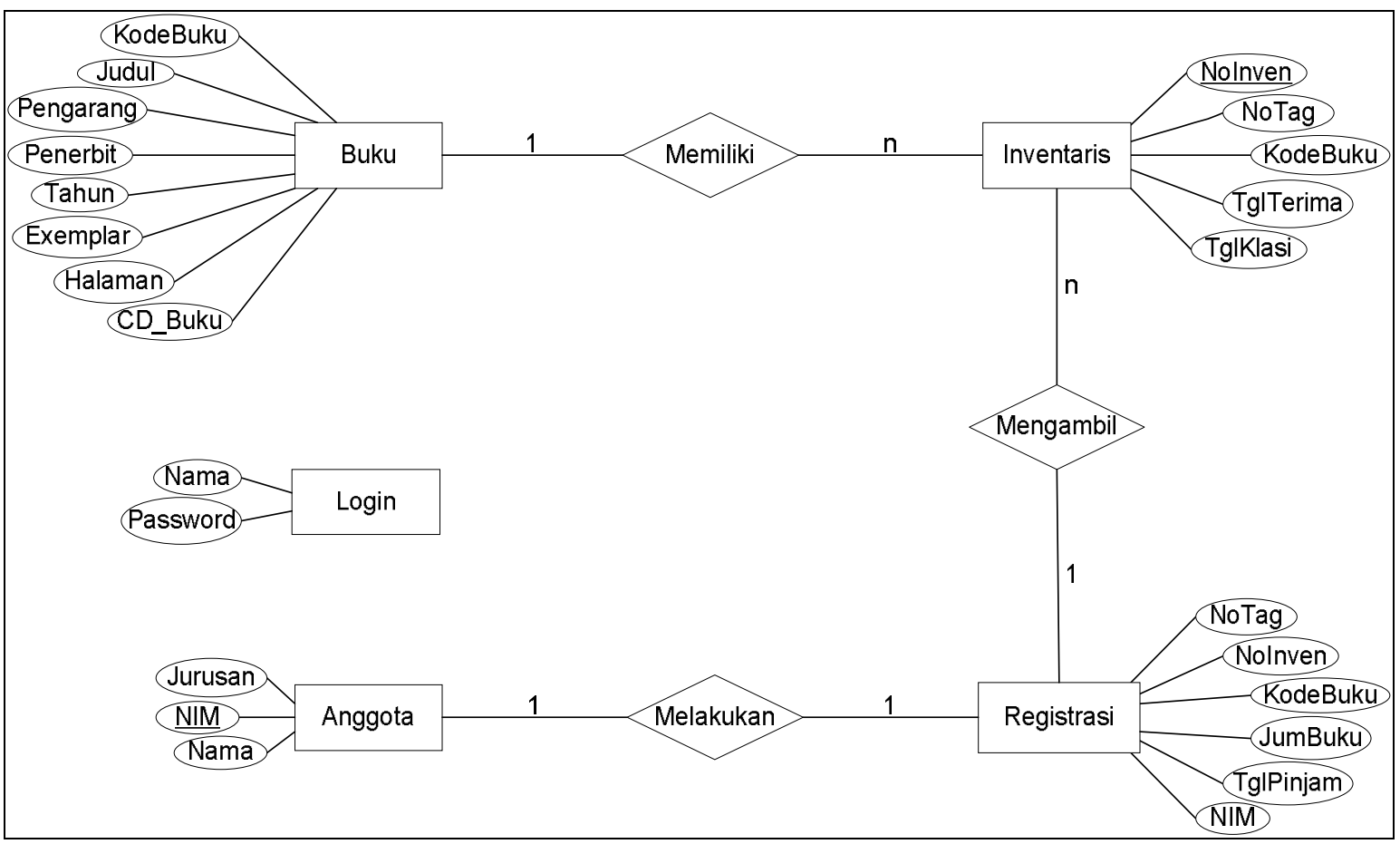

Gambar 3.5 Entity Relation Diagram Sistem Keamanan Perpustakaan

\subsection{Hasil}

Petugas perpustakaan berhasil melakukan login maka antarmuka koneksi akan muncul tetapi terlebih dahulu petugas perpustakaan memilih tombol AKTIF pada menu utama 


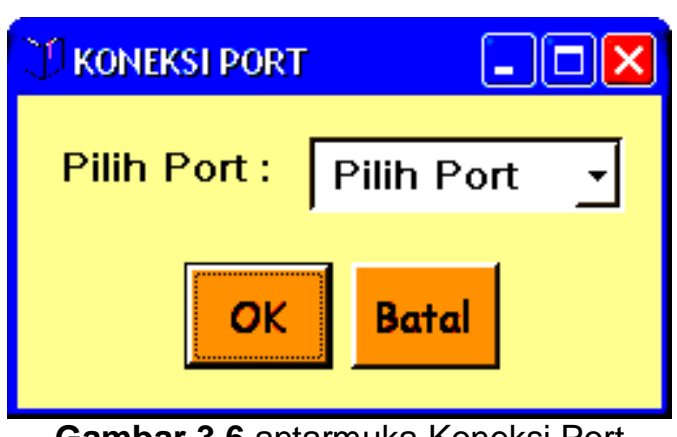

Gambar 3.6 antarmuka Koneksi Port

Tombol aktif untuk mengaktifkan menu utama yang mana akan muncul antarmuka koneksi, setelah menu aktif maka petugas perpustakaan dapat mengolah data dan akan mendapat laporan bila terdapat buku yang belum registrasi. Tombol anggota untuk masuk ke antarmuka data anggota, tombol buku untuk masuk ke antarmuka data buku, tombol inventaris untuk masuk ke antarmuka data inventaris, tombol registrasi untuk masuk ke antarmuka registrasi, tombol ubah login untuk masuk ke antarmuka olah data login dan tombol bantuan untuk melihat petunjuk penggunaan.

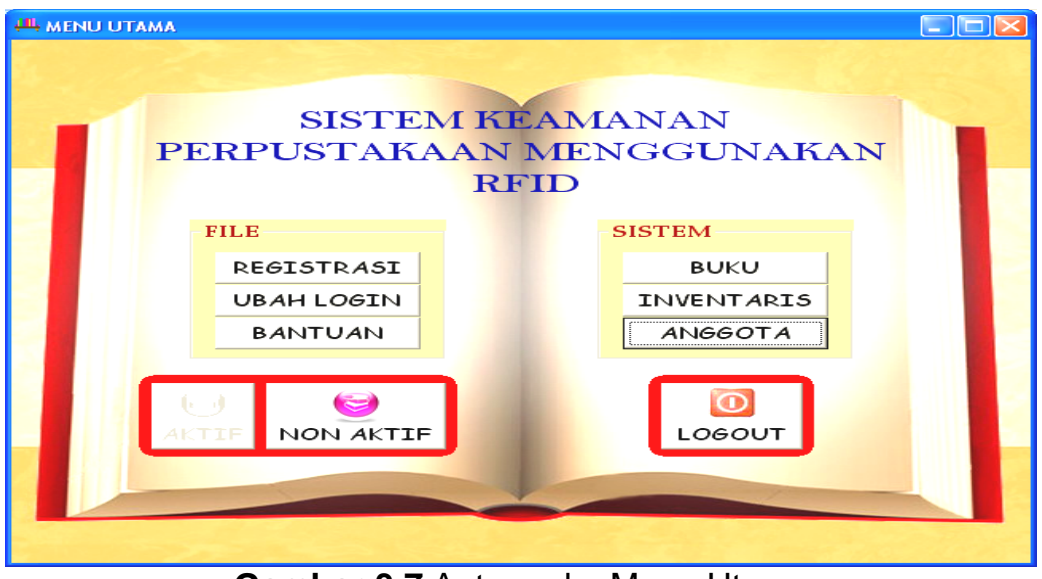

Gambar 3.7 Antarmuka Menu Utama

Petugas perpustakaan akan menjumpai antarmuka laporan bila terdapat buku yang keluar tanpa dilakukan registrasi. Antarmuka ini berfungsi untuk memberi peringatan kepada petugas, terdapat dua tombol pada antarmuka laporan, yaitu : tombol matikan alarm untuk mematikan bunyi alarm dan tombol ok untuk keluar dari antarmuka laporan.

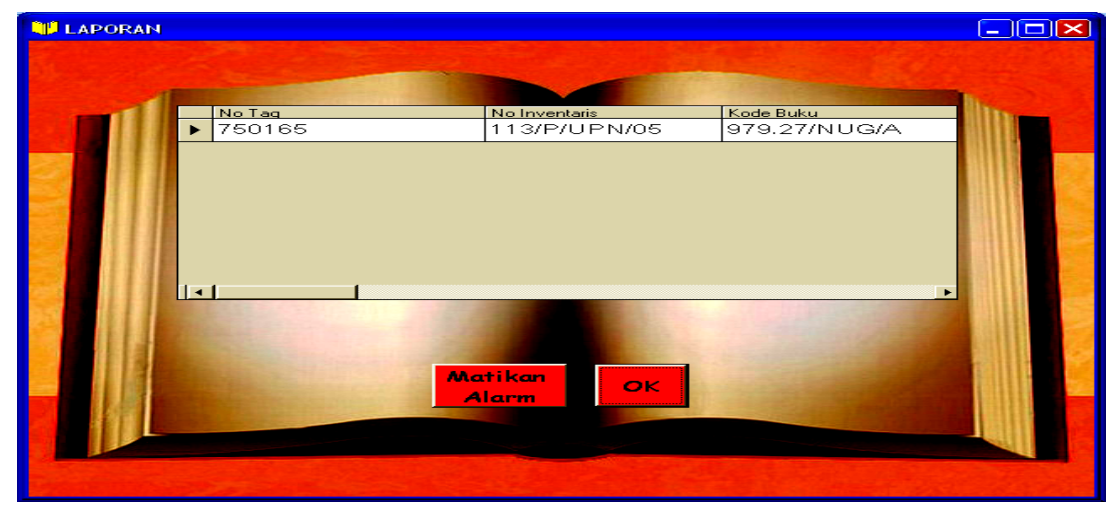

Gambar 3.8 Antarmuka Laporan

\section{KESIMPULAN}

Keamanan bahan pustaka dari kerawanan pencurian bahan pustaka bisa terjaga, dengan tetap memperhatikan kenyamanan pengunjung sehingga fungsi perpustakaan tercapai sebagai 
pusat belajar mengajar, pusat informasi, pusat penelitian sederhana dan pusat rekreasi..Sistem keamanan perlu dikembangakan dengan memberikan fasilitas antena eksternal sehingga mampu mengidentifikasi koleksi dari jarak yang lebih jauh.

\section{DAFTAR PUSTAKA}

Presetia dan Widodo, 2004, Interfacing Port Paralel dan Port Serial Komputer dengan VisualBasic 6.0, Penerbit Andi, Yogyakarta.

Anggiratih, Endang, 2010, Keamanan Perpustakaan FTI UPN"Veteran" Yogyakarta ,http://www.patrick-plaggenburg.nl/Social_RFID, 8 Juni 2009. ,http://www.itaa.org/rfid/docs/rfid.pdf, 8 Juni 2009. ,http://www.rsa.com/rsalabs/staff/bios/ajuels/publications/pdfs/rfid survey $280905 . p$ df, 8 juni 2009.

,http://www.Irs.org/documents/field stats/materials security.pdf, oktober 2010 